\title{
The Effect of Corporate Social Responsibility and the Executive Compensation on Implicit Cost of Equity: Evidence from French ESG Data
}

\author{
Yamina Chouaibi ${ }^{1}\left(\mathbb{D}\right.$, Matteo Rossi $^{2, *}$ (i) and Ghazi Zouari ${ }^{1}$ (i) \\ 1 Department of Accounting and Finance, Faculty of Economics and Management of Sfax, University of Sfax, \\ Sfax 3018, Tunisia; yamina.chouaibi@fsegs.usf.tn (Y.C.); ghazi.zouari@fsegs.usf.tn (G.Z.) \\ 2 Department of Law, Economics, Management and Quantitative Methods (DEMM), University of Sannio, \\ 82100 Benevento, Italy \\ * Correspondence: mrossi@unisannio.it
}

Citation: Chouaibi, Y.; Rossi, M.; Zouari, G. The Effect of Corporate Social Responsibility and the Executive Compensation on Implicit Cost of Equity: Evidence from French ESG Data. Sustainability 2021, 13, 11510. https://doi.org/10.3390/ su132011510

Academic Editor: Colin Michael Hall

Received: 27 August 2021

Accepted: 13 October 2021

Published: 18 October 2021

Publisher's Note: MDPI stays neutral with regard to jurisdictional claims in published maps and institutional affiliations.

Copyright: (c) 2021 by the authors. Licensee MDPI, Basel, Switzerland. This article is an open access article distributed under the terms and conditions of the Creative Commons Attribution (CC BY) license (https:// creativecommons.org/licenses/by/ $4.0 /)$.

\begin{abstract}
This research aimed to evaluate the effect of corporate social responsibility (CSR) and executive incentive compensation based on the achievement of sustainability goals on the implicit cost of equity. To test the study's hypotheses, the authors applied linear regressions on panel data using the Thomson Reuters ASSET4 and Thompson Institutional Brokers Earnings Services (I/B/E/S) database of a sample of 154 French ESG firms over the 2015-2020 period. Our results show that CSR activities lower the cost of equity capital; hence, these activities are important to shareholders' investment and financing decisions. The results have practical implications for investors and other partners interested in the business. Thus, using the implicit cost of equity is a better estimate of shareholder requirements in the context of socially responsible businesses. The results of this work could attract the attention of socially responsible investors and, especially, corporate citizens.
\end{abstract}

Keywords: corporate social responsibility (CSR); executive compensation based on sustainability; environmental; social; governance (ESG); cost of equity

\section{Introduction}

Corporate social responsibility (CSR) is a dynamic and evolving concept that concerns all organizations, given its financial and economic implications. Thus, the Commission of the European Communities has developed a broad definition of CSR as "a concept whereby companies voluntarily integrate social and environmental concerns into their business operations and their interaction with their stakeholders". Investing in CSR is a way to lower the cost of financing and maintaining a competitive advantage. In practice, major institutional investors prefer to invest in companies with better CSR performance [1]. Since state-owned enterprises and funders need to know whether better CSR performance can effectively reduce the cost of equity capital, CSR refers to all the practices implemented by companies to ensure that they respect the principles of sustainable development, i.e., being economically viable, having a positive impact on society and respecting the environment. Additionally, they will invest in profitable projects that respect ethical criteria, called socially responsible investing (SRI). In addition, investing in socially responsible projects reflects ethical behaviors that ensure sustainable development (SD), considered as a set of activities relating the company to the environment, the economy, and society, based on the tripod of Elkington (2001). It gives a better image of the company, contributes to obtaining financial resources, and makes the company more competitive in the market [2]. It is usually evaluated through the sustainability indices of the different stock exchanges in the world. The integration of the SD objectives achieved within the framework of CSR has completely changed the reality of the company, moving from a traditional to a diversified vision and opening itself more to the different meanings of environment and society [3-5]. 
Furthermore, the notion of SD occupies a central position in the valuation of companies and, consequently, in the estimation of the rate of return required by shareholders. In addition, the specificity of the social approach allows managers to meet the expectations of all the firm's partners and reduce information asymmetry and the cost of equity. In this study, executive compensation should be considered not only as a reward for the performance achieved but also as an incentive for executives to increase shareholder wealth based on the firm's SB objectives. The criteria for measuring value creation have changed as a result of this new trend in firms. As a result, the reward or remuneration of the executive is based on the achievement of the SD objectives (CEO_REM) adopted by the firms. Nevertheless, little information is communicated by companies in their annual reports on their profit-sharing policy in relation to SD objectives [4].

El Ghoul et al. (2018) [6] provide evidence that CSR reduces firms' cost of equity. French firms that are oriented to ESG are expected to provide stakeholders with more information about companies that will aid in monitoring and evaluating them and, hence, reduce the cost of equity capital. As financial transparency has been proven to affect the cost of equity $[7,8]$, it is interesting to examine how CSR interacts to affect the cost of equity capital. However, the link between CSR and the cost of equity is somewhat ambiguous, as previous literature has shown. For example, the cost of equity, which reflects the return required from an investment based on its level of risk, is disrupted by the effect of incorporating nonfinancial measures, such as the social approach of companies. Thus, the CSR performance reflected by the ratings or scores assigned reduces the information asymmetry to which the company is exposed. Since social standards affect investor preferences, companies with better CSR performance may attract a relatively larger investor base than those with poor CSR performance.

According to previous studies on the cost of equity [8-11] CSR is negatively related to the cost of equity. Besides, when the level of executive compensation depends on the degree to which SD objectives have been achieved, this negative correlation is significantly reinforced, indicating a potential substitution relationship between the executive compensation based on SD and the cost of equity. The rise in sustainability standards for executive compensation is a testament to the importance of accountability in modern and most profitable businesses. The inclusion of CSR standards in compensation can apply at different levels of the organization. In this article, we investigate the correlation between executive compensation according to the achievement of SD objectives and the cost of equity.

It is important to understand this association because the cost of equity is a determining factor for companies that engage in a CSR strategy. Therefore, our central research question is: what is the impact of CSR and the executive compensation based on SD on the cost of equity?

This research work aimed to study the impact of CSR and executive compensation based on the achievement of SD objectives on the cost of equity. We mobilized linear regressions with panel data using the Thomson Reuters ASSET4 and I/B/E/S databases of the French market to analyze data from 154 firms belonging to the ESG index between 2015 and 2020.

This work offers two main contributions to the literature. First, the use of the implicit cost of equity is a better estimate of shareholder requirements in the context of socially responsible firms. Second, CSR is considered a criterion for valuing firms, thus reducing the shortcomings of accounting information.

The remainder of this article is organized as follows. Section 2 outlines the literature review and theoretical framework. In Section 3, we develop the research hypotheses. The research design is described in Section 4, while the results and discussion are discussed in Section 5. The penultimate section (Section 6) outlines the robustness checks. Finally, Section 7 concludes the paper. 


\section{Literature Review and Theoretical Framework}

The debate in this research paper concerns the effect of CSR and executive compensation based on the achievement of SD objectives on the implicit cost of equity of French firms belonging to the ESG index. To answer this question, we first present the implicit cost of equity of the social approach, and then we show the theoretical framework that allows us to estimate the consequences of adopting activities. Finally, we put forward our two hypotheses on the impact of CSR and executive compensation based on the achievement of SD objectives on the cost of equity.

\subsection{Cost of Equity within the Framework of CSR Activities}

The cost of equity is a fundamental concept in finance. Indeed, this element is used in the choice of investment as well as the assessment of the company's value for well-defined objectives. Therefore, its evaluation requires concentration and an understanding of the different variables that can influence, far or near, the determination of the cost of equity, hence, the emergence of several theories and approaches in the field of finance, each of which tries to bring elements of answer and hypotheses to understand this concept of cost of financing. Of course, each of these approaches has advantages and disadvantages; thus, it is hard to decide on the most rational one. There are two approaches to estimating the cost of equity: the classic approach and the modern one. The former is based on an ex post measurement, i.e., based on historical data, and has some limitations; hence the appearance of the latter, which is based on forecast data, i.e., an ex ante measurement calculated in advance, to help the shareholder estimate the cost of equity, called the implicit cost of equity, based on forecast data and not historical data [10].

Our dependent variable, i.e., the implicit cost of equity, has been the subject of interest in several research areas. In fact, some researchers have also paid attention to the impact of corporate taxation, audit quality, and internal control protection on the cost of equity. Contrary to the abundant literature on the implicit cost of equity, only a few studies have been conducted on the connection between the cost of equity and CSR or the executive compensation based on SD. For example, Dhaliwal et al. [12] state that information on social responsibility could reduce information asymmetry and, therefore, reduce the cost of equity.

The best-performing companies in terms of CSR have a very low cost of equity as they continuously improve employees' welfare and the protection of their environment [13]. However, if the firms belong to "sin" industries' sectors, such as tobacco or nuclear energy, the firms' cost of equity capital increases because of their environmental and social impacts. Thus, CSR can influence firms' cost of equity by reducing information asymmetry and environmental and social costs independently of market conditions.

According to the stakeholder theory, a reputation for being socially responsible would indicate a well-balanced approach between shareholders and other stakeholders, which creates sustainable value and shares it among them. This would thus improve potential investors' belief in the future generation of the company's free cash flow. Furthermore, a study by $\mathrm{Xu}$ et al. [14] showed that, over the years, China has become aware of the importance of CSR. CSR activities also reduce the cost of equity by reducing information asymmetry when the market is assumed to be perfect, the information is complete, and the processing of this information is timely and accurate [3].

\subsection{The Theory of Stakeholders: Valuation of CSR Activities}

The "stakeholders" theory is the theory that is most frequently used by both researchers and organizations in the field of CSR [15]. This theory considers that the company or organization is at the heart of a set of relationships not only with shareholders but also all the actors interested or involved in the company's activities and decisions. The term "stakeholder" originally appeared in 1963 in the United States to designate "the groups without whom an organization would cease to exist". In other words, it refers to groups for whom the company has a responsibility. This concept made its way between controversy 
and acceptance until the 1980s, when the work of Freeman (1984), relayed by many other works, made it possible to draw up an inventory or representations of the stakeholders of a company.

The company must therefore adjust its objectives to give each of them a fair share of satisfaction. Although profit is one of these satisfactions, it does not necessarily have a predominant place in this set of objectives [16]. The rational level consists of knowing who the firm's stakeholders are and what their demands are. At the process level, it is a question of whether the firm manages its stakeholders implicitly or explicitly. According to Freeman [17], processes that are already reasonably effective in firms could be made even more effective if multiple stakeholders were taken into account. At the transactional level, Freeman [17] argues that firms need to understand the transactions between the firm and its stakeholders to see if they fit well at the rational and process levels; i.e., first, managers know whether they are legitimate stakeholders, and second, whether there are regular processes for bringing stakeholders' concerns to the fore. Thus, Max [16] proposes to build an approach to strategic management where stakeholders are systematically taken into account. For their part, Clarkson; Mitchell et al. [18,19] have contributed to deepening the typology of stakeholders by indicating that primary stakeholders are those who are directly involved in the economic process and have an explicit contract with the firm, such as shareholders, employees, customers, and suppliers.

However, secondary stakeholders are those who have voluntary or non-voluntary relationships with the firm within the framework of a rather implicit or moral contract. For his part, Clarkson [18] established a typology with two categories of stakeholders, described as voluntary and involuntary, in relation to the risk the firm represents. Thus, for him, voluntary stakeholders are those who accept to be exposed to certain risks because they invest a form of human or financial capital in the firm, whereas involuntary stakeholders are those who suffer the risk without establishing any relationship with the firm. Mitchell et al. [19] implemented a tripartite typology in terms of urgent, powerful, and legitimate stakeholders. They identified factors that explain the attention paid by managers to certain types of stakeholders in a context of limited time resources where power is held by groups of actors who can influence the firm's current or future decisions.

\section{Development of Research Hypotheses}

In this study, we developed two hypotheses related to the effect of CSR activities on the implicit cost of equity. The first hypothesis focuses on the effect of CSR on the implicit cost of equity, and the second relates the effect the executive compensation based on SD on the implicit cost of equity.

\subsection{CSR and Cost of Equity}

The relationship between CSR and the cost of equity is more or less ambiguous, as previous literature has shown. The CSR performance, reflected in the ratings or scoring assigned, reduces the information asymmetry to which the company is exposed.

Thereby, the idiosyncratic risk of the firm is better diversified, and the benefits of CSR on the cost of equity capital are evident [12]. Their findings revealed that CSR-initiating firms with high returns tend to attract more institutional investors and analysts, which will lead to a lower cost of equity capital. In addition, while raising equity capital, these companies are more likely to raise capital.

El Ghoul et al. (2011) [13] demonstrate that firms can benefit from CSR investments in minimizing the cost of equity capital. In this sense, Sharfman and Fernando [20] show that improved environmental risk management reduces the cost of equity. In addition, [21] note that CSR commitment can lead to lower financing costs resulting from an improved credit rating. They also report that investments, particularly in environmental policies, product strategies, and employee relations, contribute to reducing the cost of equity. Additionally, firms increase their level of voluntary disclosure in order to raise capital in the future at a lower cost, suggesting that firms with a relatively higher cost of equity have a greater in- 
centive to improve nonfinancial disclosure. Based on these arguments, our first hypothesis is as follows:

Hypothesis 1 (H1). Corporate social responsibility has a negative effect on the cost of equity.

\subsection{Executive Compensation Based on Sustainable Development and the Cost of Equity}

Executive compensation is a widely discussed topic in the prior literature from different theoretical perspectives. Existing empirical results suggest that greater executive pay disparity decreases the cost of equity capital. Thus, a firm with a high managerial pay disparity could reduce the risk premium and, consequently, the cost of financing firms. Research from the United States provides evidence that executive pay disparity is negatively associated with the implicit cost of equity capital [22,23].

In this regard, some authors (e.g., [24,25] assume that executive compensation bonus payments seem to present a paradox in terms of their contribution to firms belonging to the ESG index. Their use could also be associated with the characteristics of certain companies and should represent a crucial and relevant strategy to scale back the value of equity. For instance, the compensation system allows the company's employees to share the advantages through appreciation and may encourage retention, particularly if there are stock options. Previous studies show that debt-like compensation reduces the value of debt [26].

Executive compensation based on SD has been employed by many public and a few private companies to scale back the cost of equity capital [26-28]. For instance, Li and Liu [29] suggest that the adoption of executive compensation schemes is on behalf of shareholders and not creditors.

Therefore, internationally developed companies are more likely to be rated on their social, environmental, and ethical performance. As a result, they are encouraged to include a CSR-related component in the variable portion of their executives' compensation. In this research, it is assumed that CEO_REM goals align the executive's interests with those of shareholders, which might have implications for lowering the cost of equity capital. Its use may relate to the characteristics of some firms and represent a crucial and relevant strategy to scale back the cost of equity capital.

Furthermore, CEO_REM should be viewed not only as a reward for performance but also as an incentive for executives to increase shareholder wealth, hence, our second Hypothesis (H2), which is as follows:

Hypothesis 2 (H2). Executive compensation based on sustainable development has a negative impact on the cost of equity.

\subsection{COVID-19 and the Cost of Equity}

The outbreak of the COVID-19 pandemic was an unexpected shock to the global stock markets. Everyone has been negatively affected by the COVID-19 crisis, which has changed the way people live and businesses operate. Although the pandemic has brought considerable uncertainty to the economy, it has allowed companies to rethink corporate policies that can move the business forward smoothly.

The beginning of the year 2020 was characterized by the spread of coronavirus worldwide. To face this virus, the public and private sectors are voluntarily committed to protecting human beings. Therefore, private sector companies found in the commitment to face COVID-19 are a form of being socially responsible. It follows that the effect of companies, in this case, is integrated into CSR. Thus, the spread of COVID-19 strengthens and distinguishes companies to be socially responsible or not, with instant financial and economic consequences [30]. 
The global COVID-19 pandemic started as a health crisis and quickly turned into an economic crisis. Its negative effects on the global economy may be enormous and may even exceed those of the last financial crisis. To slow the spread of COVID-19, voluntary social distancing, containment, and curfew measures have been adopted in cities and nations at various times. These actions inevitably led to an economic downturn. Consumer service businesses were forced to close or operate at reduced capacity. Unemployment rates reached record highs. Demand for goods and services in many sectors collapsed. For example, the U.S. economy experienced two consecutive quarters of declining GDP after the peak of economic activity [31].

COVID-19 represents a type of downstream risk that has been overlooked and/or undervalued by investors for a long time. The probability of such a contagious, global disease event is very low, so many people, even professional financial analysts, are largely unaware of this type of risk. However, the current pandemic demonstrates that such an event can be disastrous and create enormous economic damage globally. Therefore, rational investors should adjust their equity risk assessment accordingly. Moreover, the increase in the cost of equity capital is more pronounced in firms with high exposure to COVID-19, as these firms are more likely to experience the negative economic effects of the pandemic [32]. All sectors are affected by this crisis and health risk. Therefore, COVID-19 multiplies the risks of companies, which will increase the cost of financing businesses. In this sense, shareholders will demand a higher rate of return, and thus the cost of equity will increase. Based on what has been put forward, our third hypothesis is as follows:

Hypothesis 3 (H3). Coronavirus (COVID-19) increases the cost of equity.

\section{Research Design}

\subsection{Sample Selection and Data Sources}

Our study focused on socially responsible companies belonging to the ESG index in the French context. We obtained detailed information from the ASSET4 database (Data Stream) and (I/B/E/S). Our initial sample was composed of 407 French companies belonging to the ESG index for six years, from 2015 to 2020 . Our empirical study was limited to nonfinancial firms. Thus, financial firms were eliminated due to the specificity of their accounting methods. This choice is explained by the fact that these firms are engaged in CSR activities. As a result, our final sample was composed of 154 French companies belonging to the ESG index, hence 924 firm-year observations. The best-performing industry classification system ("Industry classification benchmark", 2010) used by the Euronext exchange seems to be the most appropriate classification for French companies. We therefore chose eight sectors that group together nonfinancial companies that are likely to have social and environmental considerations as an issue: electricity, industrial engineering, buildings, mining, pharmaceuticals, electronic equipment, general industries, and oil and gas. Table 1 shows the distribution of our sample by sector of activity.

Table 1. Sample breakdown by industry.

\begin{tabular}{ccc}
\hline Industry & Observations & \% \\
\hline Electricity & 90 & 9.74 \\
Industrial engineering & 75 & 8.11 \\
Buildings and building materials & 165 & 17.85 \\
Industrial metals and mining & 160 & 17.31 \\
Pharmacy and biotechnology & 112 & 12.12 \\
Electronic and electrical equipment & 120 & 12.98 \\
General industries & 101 & 10.93 \\
Oil and gas producers & 101 & 10.93 \\
\hline Total & 924 & 100 \\
\hline
\end{tabular}




\subsection{Measurements}

The variables in this article can be classified into three types, namely, the dependent variable, the independent variables, and the control variables.

\subsubsection{Dependent Variable: Cost of Equity (" $\mathrm{R}_{\mathrm{AVG}}$ ")}

Following several research works on the cost of equity (e.g., [33,34], we measured the ex ante implicit cost of equity by actual stock prices and analyst earnings forecasts. In line with prior research, we derived it as the internal rate of return in four different valuation models. The four models were by Claus and Thomas [35], Gebhardt et al. [36], Easton [37], and Ohlson and Juettner-Nauroth [38]. Therefore, we used the average of the four individual costs of equity estimation models $\left(\mathrm{R}_{\mathrm{AVG}}\right)$ as indicators of a firm's implicit cost of equity. This eliminates the unique characteristics of any of the four models that could potentially bias the results $[9,10,13]$.

For details, Appendix A section summarizes these four models.

\subsubsection{Independent Variables}

Several explanatory variables related to French companies belonging to the ESG index can be mobilized to test their impacts on the implicit cost of equity. We focused on two main variables: CSR_SCORE and CEO_REM.

\section{- Corporate social responsibility (“CSR_SCORE”)}

Most studies have used Thomson Reuters ASSET4 to estimate CSR. Following the literature, this study also used ESG scores as reported by ASSET4. This score is based on the extent of CSR of companies regarding their ESG contributions; the range of ESG scores varies from 0 to 100 .

\section{- Executive compensation based on SD (“CEO_REM")}

As discussed in the literature review, most studies decompose executive compensation based on sustainable development into social and performance scores. In this study, we will adopt a measure developed by ASSET4 to assess executive compensation based on the achievement of sustainable development objectives. We used the variable "Remuneration policy/Incentives for sustainable development remuneration" of ASSET4. More precisely, we used the binary indicator (CEO_REM), taking a value of 1 for each year during which the company declared having inserted explicit CSR objectives in the executive compensation contracts, and 0 otherwise [39].

- The coronavirus ("COVID-19")

"COVID-19" is a dummy variable that takes the value of 1 if the study period is 2020, and 0 otherwise [40].

\section{- Control Variables}

Following previous works, we included several control variables related to the characteristics of the company and its environment in our model. We retained as control variables: the effect of ethical behavior of countries (ETHI_COUNT). The firm size (FIRM_SIZE) is measured as the natural log of total assets [41,42]. There have been several topical research works on the subject measure sector membership by a dichotomous variable. Therefore, the polluting sector (POL_SECTOR) was measured by a binary variable which takes the value of 1 if the company belongs to the following sectors of activity: chemicals, electricity, oil and gas producers, gas, utilities and consumable petroleum, metals, and mining, buildings and building materials, and automatic components, and 0 otherwise. The market-to-book ratio (MTB) is defined as the ratio between the book and the market costs of equity at the beginning of the year. It is used to determine the market value of a company in relation to its real value. A higher ratio implies an undervaluation of the company, as the book value is higher than the market value. The ratio serves as a distress risk factor as it is found to be higher for companies in financial distress. A higher ratio implies higher perceived 
risk. Thus, it has a positive relationship with the ex ante cost of equity. Finally, we added dummy variables to control for the year (YEAR) and industry (INDUSTRY) fixed effects. For more details, all the variables in our model are defined in Table 2.

Table 2. Description of the variables.

\begin{tabular}{|c|c|c|}
\hline Variables & Measures & Authors \\
\hline \multicolumn{3}{|c|}{ Dependent variable } \\
\hline Cost of equity $\left(\mathrm{R}_{\mathrm{AVG}}\right)$ & $\begin{array}{l}\text { Average of implicit cost of equity } \\
\text { models from Claus and Thomas } \\
\text { [35], Gebhardt et al. [36], Easton } \\
\text { [37], and Ohlson and } \\
\text { Jüttner-Nauroth [38]. }\end{array}$ & {$[9,10]$} \\
\hline \multicolumn{3}{|c|}{ Explanatory variables } \\
\hline $\begin{array}{l}\text { Corporate social responsibility } \\
\text { (CSR_SCORE) }\end{array}$ & $\begin{array}{l}\text { A combined score of the four } \\
\text { dimensions (economic, social, } \\
\text { environmental, and governance) }\end{array}$ & {$[43,44]$} \\
\hline $\begin{array}{l}\text { Executive compensation } \\
\text { based on the achievement of } \\
\text { SD objectives (CEO_REM) }\end{array}$ & $\begin{array}{l}\text { We used the binary indicator } \\
\text { CEO_REM, taking the value of } 1 \\
\text { each year that the company } \\
\text { declared to have inserted } \\
\text { sustainability objectives in the } \\
\text { executive compensation contracts, } \\
\text { and } 0 \text { otherwise. }\end{array}$ & {$[4]$} \\
\hline Coronavirus (COVID-19) & $\begin{array}{l}\text { This variable is binary is } 1 \text { if the } \\
\text { study period is } 2020 \text {, and } 0 \\
\text { otherwise. }\end{array}$ & [40] \\
\hline $\begin{array}{l}\text { Country ethics } \\
\text { (ETHI_COUNT) }\end{array}$ & $\begin{array}{c}\text { Scores in this index range from } \\
\text { one to seven, with one indicating } \\
\text { a very low level of country ethics } \\
\text { and seven indicating a very high } \\
\text { level. }\end{array}$ & [45] \\
\hline Firm size (FIRM_SIZE) & $\begin{array}{l}\text { Estimated by the natural } \\
\text { logarithm of total assets. }\end{array}$ & {$[41,42]$} \\
\hline $\begin{array}{l}\text { Polluting sector } \\
\text { (POL_SECTOR) }\end{array}$ & $\begin{array}{l}\text { A binary variable which takes } \\
\text { value } 1 \text { if the company belongs to } \\
\text { a polluting industry, and } 0 \\
\text { otherwise. }\end{array}$ & [46] \\
\hline Market-to-book ratio (MTB) & $\begin{array}{c}\text { This is the ratio of the book cost of } \\
\text { equity to the market value of } \\
\text { equity. }\end{array}$ & {$[8]$} \\
\hline
\end{tabular}

\subsection{Regression Model}

To test our two hypotheses, the regression model in Equation (1) is posited. YEAR and INDUSTRY stand, respectively, for year and industry random effects; $\varepsilon$ is the error term, and the indices $i$ and $t$ represent the companies and the year, respectively.

(Model 1)

$R_{A V G i, t}=\beta_{0}+\beta_{1} E N V T \_S C O R E_{i, t}+\beta_{2} S O C I \_S C O R E_{i, t}+\beta_{3} E C O N \_S C O R E_{i, t}+\beta_{4} G O V \_S C O R E_{i, t}$

$+\beta_{5} C E O \_R E M_{i, t}+\beta_{6}$ COVID $-19_{i, t}+\beta_{7}$ FIRM_SIZE $_{i, t}+\beta_{8} E T H I \_C O U N T_{i, t}+\beta_{9} P_{-} O L_{-} S E C T O R_{i, t}$

$+\beta_{10} M_{T H} B_{i, t}+\sum_{j=11}^{17} B_{j} Y E A R_{i, t}+\sum_{k=18}^{26} B_{k}$ INDUSTRY $Y_{i, t}+\varepsilon_{i, t}$ 


\section{Results Analysis and Discussion}

The present work aimed to empirically test the impact of CSR and executive compensation based on the achievement of sustainability objectives on the implicit cost of equity of these four models in French ESG firms.

\subsection{Descriptive Statistics}

The statistical tests show that the companies in our sample have an average cost of equity equal to (0.6323). This variable has a standard deviation equal to (0.2911), implying that this variable has relatively low volatility. Its value varies between (0.0395) and (0.9907), which is explained by the variety and heterogeneity of the sample.

The dependent variable, i.e., CSR_SCORE, is positive on average (0.7852). This implies that the level of CSR in French companies is very high. Likewise, this variable has a minimum of (0.0985) and a maximum of (0.9520). This compromises the integration and engagement of these firms in socially responsible practices. This discrepancy between the minimum and maximum value can be explained by the willingness of companies to adopt socially responsible practices, which is not viewed in the same way because our sample covers five different nationalities.

Moreover, Table 3 shows that the firm size (FIRM_SIZE) has an average of (12.306), with a minimum of (7.7004) and a maximum of (19.9251). This corroborates the results found by Angelina [47]. The market-to-book ratio (MTB) has an average of (2.324) with a minimum of (0.086) and a maximum of (6.122). This corroborates the results found by Dahiya and Singh (2020). Indeed, the fact that this ratio exceeds 1 means that the title of the company is overvalued, which explains its performance in the market.

Panel B of Table 3 highlights the binary variables relating to frequencies. Regarding the variable of executive compensation based on sustainable development objectives (CEO_REM), descriptive statistics show that $28 \%$ of the companies in the sample reported the inclusion of explicit sustainability goals in executive compensation contracts. However, $75 \%$ of the companies in our sample do not apply this compensation plan. Furthermore, concerning the pollutant sector variable (POL_SECTOR), $64 \%$ of the sample companies appear to belong to non-polluting sectors. It seems that our sample is evenly distributed. Concerning the coronavirus variable, $16 \%$ represents the companies observed during the COVID-19 period.

Table 3. Descriptive statistics.

\begin{tabular}{|c|c|c|c|c|c|}
\hline Variables & Obs. & Mean & SD & Minimum & Maximum \\
\hline \multicolumn{6}{|c|}{ Panel A: Descriptive statistics for metric variables } \\
\hline $\mathrm{R}_{\mathrm{AVG}}$ & 924 & 0.6323 & 0.2911 & 0.0395 & 0.9907 \\
\hline CSR_SCORE & 924 & 0.7852 & 0.3690 & 0.0985 & 0.9520 \\
\hline FIRM_SIZE & 924 & 12.306 & 1.1230 & 7.7004 & 19.9251 \\
\hline MTB & 924 & 2.324 & 0.425 & 0.086 & 6.122 \\
\hline \multicolumn{6}{|c|}{ Panel B: Frequencies (\%) for binary variables } \\
\hline Variables & & & & $\%$ & \\
\hline \multirow{2}{*}{ CEO_REM } & \multicolumn{2}{|c|}{1} & \multicolumn{3}{|c|}{0.25} \\
\hline & \multicolumn{2}{|c|}{0} & \multicolumn{3}{|c|}{0.75} \\
\hline \multirow{2}{*}{ COVID-19 } & \multicolumn{2}{|c|}{1} & \multicolumn{3}{|c|}{0.16} \\
\hline & \multicolumn{2}{|c|}{0} & \multicolumn{3}{|c|}{0.84} \\
\hline \multirow{2}{*}{ POL-SECTOR } & \multicolumn{2}{|c|}{1} & \multicolumn{3}{|c|}{0.36} \\
\hline & \multicolumn{2}{|c|}{0} & \multicolumn{3}{|c|}{0.64} \\
\hline
\end{tabular}




\subsection{Correlation Matrix}

We note that the fixed-effects model is excluded since our regression includes timeinvariant variables. A fixed-effects regression would lead to omitting these variables arbitrarily. Table 4 below presents the results, which allow us to affirm that all the correlation coefficients have values less than 0.6 , which leads us to conclude that the problem of bivariate multi-collinearity is perfectly absent.

Table 4. Pearson correlation matrix.

\begin{tabular}{cccccccc}
\hline Variables & $\mathbf{( 1 )}$ & $\mathbf{( 2 )}$ & $\mathbf{( 3 )}$ & $\mathbf{( 4 )}$ & $\mathbf{( 5 )}$ & $\mathbf{( 6 )}$ & $\mathbf{( 7 )}$ \\
\hline CSR_SCORE (1) & 1 & & & & & & \\
CEO_REM (2) & 0.1623 & 1 & & & & & \\
COVID-19 (3) & 0.0123 & 0.1280 & 1 & & & & \\
ETHI_COUNT (4) & 0.0134 & 0.0427 & 0.1678 & 1 & & & \\
FIRM_SIZE (5) & 0.0294 & 0.0441 & -0.0295 & 0.2345 & 1 & 1 & 1 \\
POL_MECTOR (6) & 0.0949 & 0.1496 & 0.0305 & 0.2485 & 0.0198 & 0.0981 & \\
MTB (7) & 0.1590 & 0.0982 & 0.2369 & 0.3690 & 0.0917 & & \\
\hline
\end{tabular}

\subsection{Discussion of Results}

Our analysis started by estimating the average implicit cost of equity for each firm over each year (2015-2020) using firm-level data. We used a panel regression analysis to identify the effects of corporate social responsibility and executive compensation based on the achievement of sustainable development goals on the implicit cost of equity.

The first hypothesis (H1), which tests whether CSR_SCORE negatively influences the implicit cost of equity, is validated. As can be seen from Table 5, the relationship between CSR and the average implicit cost of equity $\left(R_{A V G}\right)$ is negative and significant. Indeed, the examination of causal relationships shows that the coefficient associated with the link between CSR_SCORE and the cost of equity is negative $(-0.0639)$ and statistically significant (the associated t-statistic is $(-8.59)$ ). In other words, our results highlight the contribution of CSR behavior to lowering the cost of equity. In an uncertain context, decision makers are required to have tools of power over the costs of equity to invest them in a favorable climate. Indeed, over the last decade, access to equity information has become easier, and companies have become more transparent through the CSR_SCORE, which is a very important strategy for good corporate governance $[48,49]$.

In this regard, the effect of CSR on the costs of equity capital has gained momentum since the emergence of the financial scandals that ravaged the business world. Furthermore, previous works show that investors prefer to invest in companies that perform better in terms of CSR [1]. This result corroborates that of El Ghoul et al. [9], who found that companies with a better CSR_SCORE have a lower financing cost. Thus, the results support the arguments in the literature that socially responsible companies have a higher valuation and a lower risk.

The second hypothesis (H2) studies the relationship between CEO_REM and the cost of equity. The validity of this assumption is explained by the increased importance of executive compensation and its role in the cost of equity. As can be seen in Table 5, our second hypothesis (H2) is not validated. Consequently, there is a negative and insignificant relationship between CEO_REM and the implicit cost of equity. Our study offers significant contributions to the literature on the relationship between CEO_REM and the cost of equity. Thus, we show that the sensitivity of the executive compensation plan does not influence the cost of equity. These results are consistent with the idea that the sensitivities of the executive compensation plan have opposing effects on overall business risk. Our findings also add new evidence to the empirical literature on the cost of equity. This differs from the previous results found in particular by Czarniewski [50]. The results found in this study assert that wealth sensitivities lower the cost of equity. Regarding the third hypothesis, which tests whether COVID-19 positively influences the cost of equity ( $\left.\mathrm{R}_{\mathrm{AVG}}\right)$, 
the results show that this hypothesis is validated (H3) (Table 5). Thus, the findings of the study indicate that there is a positive (0.102) and statistically significant relationship between COVID-19 and $\mathrm{R}_{\mathrm{AVG}}(p<0.05)$. In fact, the new business valuation standards have attracted the attention of some stakeholders. This can be explained by the importance of environmental protection, which is becoming an unquestionable international issue, and especially with the COVID-19 epidemic, which has highlighted the need to protect our planet [51-53]. The results found also add new evidence to the empirical literature on the cost of equity. They corroborate previous results found by Bae et al. [40]. Hence, our results assert that COVID-19 increases the cost of equity.

The control variables show their expected signs and are generally statistically significant. The statistical results show that our four control variables have significant effects on the implicit cost of equity. Regarding our first control variable, "Country ethics" (ETHI_COUNT), our results show that the ethical behavior of countries has a positive and significant effect on the implicit cost of equity, which will reduce information asymmetry and conflicts of interest between the various stakeholders. Table 5 shows that there is a positive relationship between firm size (FIRM_SIZE) and the implicit cost of equity. This shows that the size of the company helps to reduce the cost of equity. This result is consistent with, among others, the results of $\mathrm{Li}$ and Liu [29].

Moreover, the influence of the pollutant sector (POL_SECTOR) on French firm decisions has become a widely discussed subject in academia. With respect to the present work, one could note that this control variable turns out to be positively and significantly correlated (at the $5 \%$ level) with the cost of equity, which makes it possible to reduce information asymmetry [46]. Finally, we find a significant positive relationship between the book-to-market ratio (BTM) and cost of equity $(\beta=0.0292, p<0.05)$. These results confirm those found by Dahiya and Singh [8].

Table 5. Regression results of cost of equity.

\begin{tabular}{ccc}
\hline \multicolumn{2}{c}{ Dependent Variable } & $\mathbf{R}_{\text {AVG }}$ \\
\hline Variables & Coefficient & $t$-Statistic \\
\hline Constant & $0.3581^{* * *}$ & 5.34 \\
\hline CSR_SCORE & $-0.0639^{* * *}$ & -8.59 \\
\hline CEO_REM & -0.0015 & -0.43 \\
\hline COVID-19 & $0.102^{* *}$ & 1.98 \\
\hline FIRM_SIZE & $0.1736^{* * *}$ & 3.41 \\
\hline ETHI_COUNT & $0.0170^{* * *}$ & -5.45 \\
\hline POL_SECTOR & $0.19791^{* *}$ & 2.54 \\
\hline MTB & $0.0292^{* *}$ & \\
\hline Year fixed effect & YES & \\
\hline Firms fixed effect & YES & \\
\hline F $(p$-value $)$ & $2.41(0.000)$ & \\
\hline $\mathrm{R}^{2}$ & 0.3414 & \\
\hline With: ${ }^{* *}, * *$ significance at $p<0.05$, and $p<0.10$, respectively.
\end{tabular}

\section{Robustness Checks}

To obtain more relevant and more robust results, it is fundamental to examine the effect of the four aspects of CSR_SCORE individually (social score, economic score, environmental score, and governance score) on the implicit cost of equity. More precisely, we will regress the effect of the four dimensions of CSR as well as the other independent and control variables on the variable of interest, namely, the implicit cost of equity.

The model to be tested is as follows:

(Model 2) 


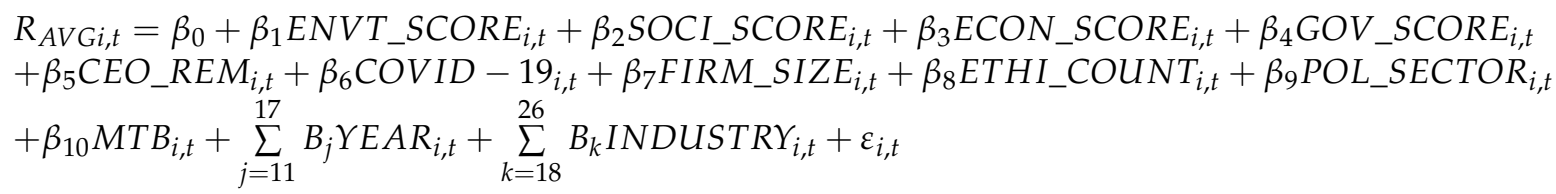

As for the other models, the estimation of this last model was carried out by the STATA 17 data analysis software. The results of the estimation of the model presented in Table 6, after checking the necessary econometric tests, indicate that the regression coefficients relating to the three components of CSR (environmental score, social score, and governance score) are negative and statistically significant, except for the economic score component (ECON_SCORE), which is statistically insignificant. Interestingly, the main pillars of CSR appear to have a negative and significant impact on lowering the cost of equity. However, the economic pillar of CSR does not affect our explanatory variable.

The results found in this robustness model indicate the importance of the recommended CSR approach and the need to design a standard model of business management by promoting CSR as a management tool of the firm.

Table 6. Robustness checks.

\begin{tabular}{|c|c|c|c|}
\hline Variables & Coefficient & T-Stud & $p$-Value \\
\hline ENVT_SCORE & $-0.9551 *$ & -253.71 & 0.000 \\
\hline SOCI_SCORE & $-0.0140 *$ & -3.11 & 0.002 \\
\hline ECON_SCORE & -0.0008 & -0.27 & 0.788 \\
\hline GOVE_SCORE & $-0.0046^{* * *}$ & -1.86 & 0.062 \\
\hline CEO_REM & 0.0014 & 1.21 & 0.224 \\
\hline COVID-19 & $0.102 *$ & 1.98 & 0.055 \\
\hline FIRM_SIZE & -0.0006 & -1.02 & 0.306 \\
\hline ETHI_COUNT & 0.00030 & 0.03 & 0.974 \\
\hline POL_SECTOR & $0.0031^{* *}$ & 2.27 & 0.023 \\
\hline MTB & $0.2037^{* *}$ & 2.34 & 0.019 \\
\hline Constant & 0.2111 & 6.21 & 0.000 \\
\hline Year-fixed effect & & YES & \\
\hline Industry—fixed effect & & YES & \\
\hline F ( $p$-value) & & $15.11(0.000)$ & \\
\hline Specific effect & & YES & \\
\hline Hausman ( $p$-value) & & $3.66(0.8180)$ & \\
\hline Breusch-Pagan test ( $p$-value) & & $7184.63(0.0000)$ & \\
\hline Modified Wald test & & - & \\
\hline Wooldridge test & & $93.800(0.000)$ & \\
\hline Wald chi2 ( $p$-value) & & $1462.19(0.000)$ & \\
\hline$R^{2}$ & & 0.2748 & \\
\hline
\end{tabular}

\section{Conclusions}

This present work aimed to study the relationship between CSR, CEO_REM, COVID19, and the cost of equity in French firms belonging to the ESG index between 2015 and 2020. This work attempted to fill the gap in the literature by theoretically and empirically investigating the relationship between CSR and the firm's cost of equity. Several previous 
studies have found that engagement in CSR can contribute to enjoying a lower cost of equity. This can be attributed to the fact that companies have become more transparent thanks to CSR, which is a fundamental strategy of good governance to reduce agency costs and information asymmetry.

The empirical results also show that executive compensation based on the achievement of SD goals (CEO_REM) is negatively associated with the cost of equity. Therefore, CEO_REM is an ineffective mechanism to incentivize the executive to enforce good conduct and strengthen CSR practices. The empirical results also show that COVID-19 is positively associated with the cost of equity. As a result, the financial market will take into account a new type of risk, and consequently, the cost of financing companies will increase. Shareholders will demand a higher rate of return because of the risk.

This article makes an original contribution to the accounting and finance literature in several important areas, such as ESG. In addition, this article postulates that French ESG firms, which take social interests into account in developing their strategies, will be able to reduce the cost of equity capital. Consistent with this result, firms can evaluate their processes and become more aligned with green practices, and investors have a strong incentive to invest in such firms. Besides, we contribute to the literature on the economic consequences of executive compensation in several ways. We show that the negative association between executive compensation and cost of equity varies with sustainability goals. Our results show that CSR decreases the cost of equity. This can be explained by the importance of these practices in the investment decision and on the attitude of responsible investors. Our results also reveal that companies in the ESG index have a very low cost of equity capital and that, in this context, CSR is a central determinant of the cost of equity capital.

Our study has two main limitations: First, the choice of the sample is limited to French companies only, hence the absence of Anglo-Saxon companies. Second, the absence of endogeneity tests, i.e., the relationship between CSR activities, COVID-19, and the cost of equity, could be studied in both directions.

Author Contributions: Conceptualization, Y.C and G.Z.; methodology, M.R.; software, Y.C.; validation, M.R., G.Z. and Y.C.; formal analysis, Y.C.; investigation, G.Z.; resources, M.R.; data curation, M.R.; writing—original draft preparation, Y.C.; writing—review and editing, M.R.; visualization, Y.C.; supervision, G.Z.; project administration, M.R.; funding acquisition, M.R. All authors have read and agreed to the published version of the manuscript.

Funding: This research received no external funding.

Institutional Review Board Statement: Not applicable.

Informed Consent Statement: Not applicable.

Conflicts of Interest: The authors declare no conflict of interest.

\section{Appendix A}

\section{Appendix A.1. Cost of Equity Models}

In order to compute a firm's ex ante cost of equity, the main dependent variable in this paper, we used four different implied cost of equity models proposed by Claus and Thomas [35], Gebhardt et al. [36], Easton [37], and Ohlson and Juettner-Nauroth [38]. In this Appendix A, we describe the four models and the underlying model assumptions in more detail. All four models are based on the discounted cash flow model but construct the pricing equation in a slightly different way. The main differences lie in the length of the explicit earnings forecast horizon and the assumptions of long-term behavior. Claus and Thomas [35] use explicit abnormal earnings forecasts for a time horizon of five years, after which earnings grow at the expected inflation rate. Gebhardt et al. [36] explicitly evaluate a three-year horizon of forecasted return on equity and let returns linearly fade to a target return on equity. In the model by Ohlson and Juettner-Nauroth [38], no explicit forecast horizon is specified, but it makes use of a near-term and a long-term earnings growth 
rate, which is the expected inflation rate. Easton [37] builds on the Ohlson and JuettnerNauroth [38] model (first disseminated in 2000) but explicitly includes two-year-ahead earnings forecasts. For our model specifications, we closely follow Hail and Leuz [33] and El Ghoul et al. [13].

Common Variables and Assumptions

$r_{c t}$ : Implied cost of equity from the Claus and Thomas [35] model;

$r_{g l s}:$ Implied cost of equity from the Gebhardt et al. [36] model;

$r_{e a}$ : Implied cost of equity from the Easton [37] model;

$r_{o j}$ : Implied cost of equity from the Ohlson and Juettner-Nauroth [38] model;

$P_{t}$ : Current stock price at date $\mathrm{t}$;

$R O E_{t+\delta}$ : Return on equity forecast for the year;

$E P S_{t+\delta}$ : Earnings per share forecast for the year;

$i_{t}$ : Expected perpetual earnings growth at time $t$;

$d p r_{t}$ : Expected dividend payout ratio at time $\mathrm{t}$;

$D P S_{t}$ : Expected dividends per share at time $\mathrm{t}$;

$l$ tg $_{t}$ : Long-term earnings growth forecast for time $\mathrm{t}$;

$B_{t}$ : Current book value per share;

$B_{t+\delta}$ : Book value per share forecast for year ${ }_{t+\delta}$, calculated using the clean surplus relation$\operatorname{ship} B_{t+\delta}=B_{t+\delta-1}+E P S_{t+\delta}\left(1-d p r_{t+\delta}\right)$.

$a e_{t+\delta}$. Abnormal earnings forecast for year ${ }_{t+\delta}$.

In all models, we required firms to have positive earnings per share forecasts for year $t=1$ and year $t=2$. Two of the models require explicit earnings forecasts for a longer forecast horizon. If forecasts for $t=3$ to $t=5$ were missing in I/B/E/S, we computed the missing data from earnings forecasts for year $t=2$ and the long-term earnings growth forecast by way of $E P S_{t+\delta}=E P S_{t+\delta-1}(1+$ ltgt $)$ according to El Ghoul et al. [13] and Breuer et al. [10]. If the forecast for long-term earnings growth was missing, we used the earnings growth rate of forecasted earnings per share from year $t=2$ to year $t=3$, if available. The models by Easton [37] and Ohlson and Juettner-Nauroth [38] can be solved in closed form with respect to a firm's cost of equity.

The other models have to be solved using numerical methods.

\section{Appendix A.2. Models Descriptions}

Model 1: Claus and Thomas [35]

In this model, the current share price is expressed in terms of the cost of equity, current book value, abnormal earnings forecasts, and perpetual abnormal earnings growth. After the 5-year explicit forecast horizon, forecasted residual earnings are supposed to grow at the expected inflation rate. Forecasted book values are computed assuming clean surplus accounting as specified above. Following Hail and Leuz [33], we assume the expected dividend payout ratio to be constant and equal to the actual dividend in year $\mathrm{t}-1$ divided by the actual earnings per share in year $\mathrm{t}-1$. For, $a e_{t+\delta}=e p s_{t+\delta}-r c t . B_{t+\delta-1}$, the valuation equation is given by:

$$
P_{t}=B_{t}+\sum_{\delta=1}^{5} \frac{a e_{t+\delta}}{\left(1+r_{c t}\right)^{\delta}}+\frac{a e_{t+5}\left(1+i_{t}\right)}{\left(r_{c t}-i_{t}\right)\left(1+r_{c t}\right)^{5}}
$$

Model 2: Gebhard et al. [36]

This model uses the current book value, ROE forecasts, book value forecasts, and the cost of equity to derive the current share price. After the 3-year explicit forecast horizon, the ROE forecasts linearly decrease to a target ROE until year 12 . The model also assumes clean 
surplus accounting. Book values are computed as described in Model 1. The valuation equation is given by:

$$
P_{t}=B_{t}+\sum_{\delta=1}^{11} \frac{R O E_{t+\delta}-r_{g l s}}{\left(1+r_{g l s}\right)^{\delta}} B_{t+\delta-1}+\frac{R O E_{t+12}-r_{g l s}}{r_{g l s}\left(1+r_{g l s}\right)^{11}} B_{t+11}
$$

In years $t+1, t+2$, and $t+3, R O E_{t_{+\delta}}$ is set equal to $E P S_{t+\delta} / b_{t+\delta-1}$. After year 3 , it linearly decreases to a target ROE. Following El Ghoul et al. [9] and Breuer et al. [10], we compute the target ROE as the country-industry-year median of the average ROE over the last 3 years for each firm. If negative, the country-industry-year median is replaced by the industry-year median. If the industry-year median is negative, we use the country-year-median.

Model 3: Easton [37]

This model is a special case of the abnormal earnings growth valuation model by Ohlson and Juettner-Nauroth [38], assuming abnormal growth in earnings to be constant: it allows the current share price to be expressed in terms of the cost of equity, one-year-ahead and two year-ahead earnings forecasts and expected dividend payout at time $t=1$. We follow El Ghoul et al. [13] and Breuer et al. [10] and assume dividends per share to be constant. The valuation equation is given by:

$$
P_{t}=\frac{E P S_{t+2}-E P S_{t+1}\left(1-r_{e a} d p r_{t+1}\right)}{r_{e a}^{2}}
$$

where $d p r_{t+1}=\frac{D P S_{t+1}}{E P S_{t+1}}=\frac{D P S_{0}}{E P S_{t+1}}$ and DPS $S_{0}$ is the actual dividend per share in year $t-1$. This leads to $r_{\text {ea }}$ according to the following equation:

$$
r_{e a}=\frac{D P S_{0}}{2 P_{t}}+\sqrt{\left(\frac{D P S_{0}}{2 P_{t}}\right)^{2}+\frac{E P S_{t+2}-E P S_{t+1}}{P_{t}}}
$$

Model 4: Ohlson and Juettner-Nauroth [38]

This model allows the calculation of share prices from the cost of equity, 1-year-ahead earnings forecasts, a near-term and a perpetual growth forecast, and the expected dividend payout. The near-term earnings growth $g_{t}$ is the average of $\mathrm{I} / \mathrm{B} / \mathrm{E} / \mathrm{S}$ long-term growth forecast and the growth of forecasted earnings per share from year $t+1$ to $t+2$. The perpetual growth rate is the expected inflation rate. Again, we follow El Ghoul et al. [13] and Breuer et al. [10] and assume dividends per share to be constant. The valuation equation is given as follows:

$$
P_{t}=\frac{E P S_{t+1}\left(g_{t}-i_{t}+r_{o j} d p r_{t+1}\right)}{r_{o j .}\left(r_{o j}-i_{t}\right)}
$$

where

$$
g_{t} \frac{1}{2}\left(\frac{E P S_{t+2}-E P S_{t+1}}{E P S_{t+1}}\right)+l t g_{t}
$$

We compute $r_{\mathrm{oj}}$ as:

$$
r_{o j} A+\sqrt{A^{2}+\frac{E P S_{t+1}}{P_{t}}}\left(g_{t}-i_{t}\right)
$$

With,

$$
A=\frac{1}{2}\left(i_{t}+\frac{D P S_{t}}{P_{t}}\right)
$$




\section{References}

1. Galema, R.; Plantinga, A.; Scholtens, B. The stocks at stake: Return and risk in socially responsible investment. J. Bank. Financ. 2008, 32, 2646-2654. [CrossRef]

2. Haseeb, M.; Hussain, H.I.; Kot, S.; Androniceanu, A.; Jermsittiparsert, K. Role of Social and Technological Challenges in Achieving a Sustainable Competitive Advantage and Sustainable Business Performance. Sustainability 2019, 11, 3811. [CrossRef]

3. Eom, K.; Nam, G. Effect of Entry into Socially Responsible Investment Index on Cost of Equity and Firm Value. Sustainability 2017, 9, 717. [CrossRef]

4. Chouaibi, Y.; Zouari, G. The effect of corporate social responsibility practices on real earnings management: Evidence from a European ESG data. Int. J. Discl. Gov. 2021, 1-20, in press. [CrossRef]

5. Sheehy, B.; Farneti, F. Corporate Social Responsibility, Sustainability, Sustainable Development and Corporate Sustainability: What Is the Difference, and Does It Matter? Sustainability 2021, 13, 5965. [CrossRef]

6. El Ghoul, S.; Guedhami, O.; Kim, H.; Park, K. Corporate Environmental Responsibility and the Cost of Capital: International Evidence. J. Bus. Ethic. 2018, 149, 335-361. [CrossRef]

7. Pham, A.V. Political risk and cost of equity: The mediating role of political connections. J. Corp. Financ. 2019, 56, 64-87. [CrossRef]

8. Dahiya, M.; Singh, S. The linkage between CSR and cost of equity: An Indian perspective. Sustain. Account. Manag. Policy J. 2020, 12, 499-521. [CrossRef]

9. El Ghoul, S.; Guedhami, O.; Wang, H.; Kwok, C.C. Family control and corporate social responsibility. J. Bank. Financ. 2016, 73, 131-146. [CrossRef]

10. Breuer, W.; Müller, T.; Rosenbach, D.; Salzmann, A. Corporate social responsibility, investor protection, and cost of equity: A cross-country comparison. J. Bank. Financ. 2018, 96, 34-55. [CrossRef]

11. Yi, Y.; Xie, B.; Zhou, L.; Wei, Y. Does CSR affect the cost of equity capital: Empirical evidence from the targeted poverty alleviation of listed companies in China. PLoS ONE 2020, 15, e0227952. [CrossRef]

12. Dhaliwal, D.S.; Li, O.Z.; Tsang, A.; Yang, Y.G. Voluntary Non financial Disclosure and the Cost of Equity Capital: The Initiation of Corporate Social Responsibility Reporting. Account. Rev. 2011, 86, 59-100. [CrossRef]

13. El Ghoul, S.; Guedhami, O.; Kwok, C.; Mishra, D. Does corporate social responsibility affect the cost of capital? J. Bank. Financ. 2011, 35, 2388-2406. [CrossRef]

14. Xu, X.; Farach-Carson, M.; Jia, X. Three-dimensional in vitro tumor models for cancer research and drug evaluation. Biotechnol. Adv. 2014, 32, 1256-1268. [CrossRef]

15. Jacqueminet, A.; Trabelsi, L. CSR Strategic Implementation in MNEs: The Role of Subsidiaries' Stakeholders. Sust. Stak. Gov. Corp. Soc. Res. 2018, 169-195. [CrossRef]

16. Max, B. Clarkson A Stakeholder Framework for Analyzing and Evaluating Corporate Social Performance. Acad. Manag. Rev. 1995, 20, 92-117.

17. Freeman, R. Strategic Management: A Stakeholder Approach; Pitman: Boston, MA, USA, 1984.

18. Clarkson, M. A stakeholder framework for analysing and evaluating corporate social performance. In The Corporation and Its Stakeholders; University of Toronto: Toronto, ON, Canada, 2016; pp. 243-274.

19. Mitchell, R.; Agle, B.R.; Wood, D.J. Toward a theory of stakeholder identification and salience: Defining the principle of who and what really counts. Acad. Manag. Rev. 1997, 22, 853-886. [CrossRef]

20. Sharfman, M.; Fernando, P. Environmental risk management and the cost of capital. Strateg. Manag. J. 2008, $29,569-592$. [CrossRef]

21. Attig, N.; Cleary, S.; El Ghoul, S.; Guedhami, O. Institutional Investment Horizons and the Cost of Equity Capital. Financ. Manag. 2013, 42, 441-477. [CrossRef]

22. Chen, Z.; Huang, Y.; Wei, K.C.J. Executive Pay Disparity and the Cost of Equity Capital. J. Financ. Quant. Anal. 2013, 48, 849-885. [CrossRef]

23. Saha, R.; Kabra, C. Does Corporate Governance Influence Voluntary Disclosure? Evidence from India. Indonesian. J. Sust. Account. Manag. 2019, 32, 203-214. [CrossRef]

24. Zhang, L. Board demographic diversity, independence, and corporate social performance. Corp. Gov. Int. J. Bus. Soc. 2012, 12, 686-700. [CrossRef]

25. Conyon, M.J.; He, L. Executive Compensation and Corporate Fraud in China. J. Bus. Ethic. 2016, 134, 669-691. [CrossRef]

26. Anantharaman, D.; Fang, V.W.; Gong, G. Inside Debt and the Design of Corporate Debt Contracts. Manag. Sci. 2014, 60, 1260-1280. [CrossRef]

27. Dhole, S.; Khumawala, S.B.; Mishra, S.; Ranasinghe, T. Executive Compensation and Regulation-Imposed Governance: Evidence from the California Nonprofit Integrity Act of 2004. Account. Rev. 2015, 90, 443-466. [CrossRef]

28. Moses, E.; Che-Ahmad, A.; Abdulmalik, S. Board governance mechanisms and sustainability reporting quality: A theo-retical framework. Cogent. Bus. Manag. 2020, 7, 1771075. [CrossRef]

29. Li, S.; Liu, C. Quality of Corporate Social Responsibility Disclosure and Cost of Equity Capital: Lessons from China. Emerg. Mark. Financ. Trade 2018, 54, 2472-2494. [CrossRef]

30. Rhee, C.; Kanjilal, S.; Baker, M.; Klompas, M. Duration of severe acute respiratory syndrome coronavirus 2 (SARS-CoV-2) infectivity: When is it safe to discontinue isolation? Clin. Infect. Dis. 2021, 72, 1467-1474. [CrossRef] 
31. Ke, Y. The Impact of COVID-19 on Firms' Cost of Equity Capital: Early Evidence from U.S. Public Firms. Financ. Res. Lett. 2021, 102242 , in press. [CrossRef]

32. Goodell, J.W. COVID-19 and finance: Agendas for future research. Financ. Res. Lett. 2020, 35, 101512. [CrossRef] [PubMed]

33. Hail, L.; Leuz, C. International differences in the cost of equity capital: Do legal institutions and securities regulation matter? J. Account. Res. 2006, 44, 485-531. [CrossRef]

34. Chen, K.; Chen, Z.; Wei, K. Legal protection of investors, corporate governance, and the cost of equity capital. J. Corp. Financ. 2009, 15, 273-289. [CrossRef]

35. Claus, J.; Thomas, J. Equity Premia as Low as Three Percent?Evidence from Analysts' Earnings Forecasts for Domestic and International Stock Markets. J. Financ. 2001, 56, 1629-1666. [CrossRef]

36. Gebhardt, W.; Charles, M.L.; Swaminathan, B. Toward an Implied Cost of Capital. J. Account. Res. 2001, 39, 135-176. [CrossRef]

37. Easton, P. PE Ratios, PEG Ratios, and Estimating the Implied Expected Rate of Return on Equity Capital. Account. Rev. 2004, 79, 73-95. [CrossRef]

38. Ohlson, J.; Juettner-Nauroth, B. Expected EPS and EPS Growth as Determinants of Value. Rev. Account. Stud. 2005, 10, 349-365. [CrossRef]

39. Derchi, G.; Zoni, L.; Dossi, A. Corporate Social Responsibility Performance, Incentives, and Learning Effects. J. Bus. Ethic. 2020, 173, 617-641. [CrossRef]

40. Bae, K.; El Ghoul, S.; Gong, Z.; Guedhami, O. Does CSR matter in times of crisis? Evidence from the COVID-19 pandemic. J. Corp. Financ. 2021, 67, 101876. [CrossRef]

41. Aragón-Correa, J. Strategic proactivity and firm approach to the natural environment. Acad. Manag. J. 1998, 41, 556-567. [CrossRef]

42. Lanis, R.; Richardson, G. Corporate social responsibility and tax aggressiveness: An empirical analysis. J. Accont. Publ. Policy 2012, 31, 86-108. [CrossRef]

43. Cui, J.; Jo, H.; Na, H. Does corporate social responsibility affect information asymmetry? J. Bus. Ethic. 2018, 148, 549-572. [CrossRef]

44. Chen, Z.; Hong, C.; Occa, A. How different CSR dimensions impact organization-employee relationships: The moderating role of CSR-culture fit. Corporate Communications. Int. J. 2019, 24, 63-78. [CrossRef]

45. Haniffa, R.; Cooke, T. The impact of culture and governance on corporate social reporting. J. Account. Publ. Policy 2005, 24, 391-430. [CrossRef]

46. Zouari-Hadiji, R.; Chouaibi, Y. Corporate ethical behavior and the cost of equity capital: Evidence from the world's most ethical companies. J. Financ. Rep. Account. 2021, in press. [CrossRef]

47. Angelina, G. Pengaruh Capital Structure, Profitability, Firm Size, Dan Firm Growth Terhadap Firm Value. J. Paradig. Akunt. 2019, 2, 255-262.

48. Servaes, H.; Tamayo, A. The Impact of Corporate Social Responsibility on Firm Value: The Role of Customer Awareness. Manag. Sci. 2013, 59, 1045-1061. [CrossRef]

49. Chen, E.; Gavious, I. Does CSR have different value implications for different shareholders? Financ. Res. Lett. 2015, 14, 29-35. [CrossRef]

50. Czarniewski, S. Corporate Social Responsibility as Value for the Customer. Int. J. Acad. Res. Account. Financ. Manag. Sci. 2014, 4, 136-142. [CrossRef]

51. He, H.; Harris, L. The impact of COVID-19 pandemic on corporate social responsibility and marketing philosophy. J. Bus. Res. 2020, 116, 176-182. [CrossRef]

52. Manuel, T.; Herron, T.L. An ethical perspective of business CSR and the COVID-19 pandemic. Soc. Bus. Rev. 2020, 15, 235-253. [CrossRef]

53. Carroll, A.B. Corporate social responsibility (CSR) and the COVID-19 pandemic: Organizational and managerial implications. J. Strateg. Manag. 2021, 14, 315-330. [CrossRef] 